\title{
Fructose Metabolism in Wild-type, Fructokinase-negative and Revertant Strains of Rhizobium leguminosarum
}

\author{
By A. R. GLENN,* R. ARWAS, I. A. MCKAY AND M. J. DILWORTH \\ Nitrogen Fixation Research Group, School of Environmental and Life Sciences, Murdoch \\ University, Murdoch, Western Australia 6150, Australia
}

(Received 27 May 1983; revised 20 September 1983)

\begin{abstract}
Rhizobium leguminosarum accumulates fructose by an active process sensitive to azide, 2,4dinitrophenol and carbonyl cyanide $m$-chlorophenylhydrazone. The fructose is not phosphorylated during transport. Sorbose and glucose interfere with fructose uptake. Inside the cell fructose is metabolized via fructose 6-phosphate; there is no evidence for an alternative metabolic route via sorbitol to glucose or via sorbitol 6-phosphate to fructose 6-phosphate. Tn5induced mutants lacking fructokinase failed to grow on fructose, mannitol or sorbitol and grew slowly on sucrose; growth was normal on all other single carbon sources tested. Growth of these mutants on a range of carbon sources was retarded by added fructose. Revertants which had regained the capacity to utilize fructose all had an unstable fructokinase which could be partially stabilized by fructose.
\end{abstract}

\section{INTRODUCTION}

Legume root nodules contain a variety of carbohydrates including sugars such as glucose, fructose and sucrose (Streeter, 1980). Fructose, both as the free sugar and as a constituent of sucrose, is potentially a carbon source for bacteroid growth and development and subsequent $\mathrm{N}_{2}$ fixation.

The requirement for fructose catabolism for the establishment of an effective symbiosis has been investigated using mutants defective in fructose uptake or phosphorylation. In Rhizobium trifolii (Ronson \& Primrose, 1979) and $R$. leguminosarum (Glenn et al., 1984) mutants defective in fructose metabolism nodulated and fixed $\mathrm{N}_{2}$. However, in $R$. meliloti (Duncan, 1981) a fructokinase mutant formed ineffective nodules. These data suggest that in the closely related $R$. trifolii and $R$. leguminosarum the capacity to utilize fructose is not essential for the development of an effective symbiosis. Nevertheless, they do not eliminate fructose as a substrate used simultaneously with other carbon compounds. A study of substrate selection in $R$. leguminosarum 3841 (Dilworth et al., 1983) indicated that in binary mixtures of carbon sources there was simultaneous utilization even though the substrates may be utilized at markedly different rates.

Little is known about the uptake and catabolism of fructose in Rhizobium except for the presence of a cytoplasmic fructokinase (Martinez-de Drets \& Arias, 1970; Ronson \& Primrose, 1979; Glenn et al., 1984). In many organisms the initial step of fructose metabolism involves a phosphoenolpyruvate-dependent phosphotransferase system (Baumann \& Baumann, 1975; Sawyer et al., 1977; Van Dijken \& Quayle, 1977). The fructose 1-phosphate is then further phosphorylated to yield fructose 1,6-bisphosphate which can then be metabolized via the Entner-Doudoroff and/or Embden-Meyerhof pathways (Sawyer et al., 1977).

During the course of a study on Tn5-induced sugar mutants of $R$. leguminosarum 3841 (Glenn et al., 1984) two fructose-negative strains were isolated which grew poorly on sucrose. This paper 
reports on the uptake system and metabolism of fructose in $R$. leguminosarum and provides an explanation for the poor growth of fructose non-utilizing strains on sucrose.

\section{METHODS}

Organism. Rhizobium leguminosarum MNF3841 is a str derivative of strain 300 (Johnston \& Beringer, 1975). Mutant strains are shown in Table 1.

Media. Bacteria were grown in batch culture at $28^{\circ} \mathrm{C}$ in the minimal salts medium of Brown \& Dilworth (1975) with $\mathrm{NH}_{4}^{+}(10 \mathrm{mM})$ as nitrogen source, phosphate at $0.3 \mathrm{mM}$, and carbon sources at $10 \mathrm{mM}$, except for glycerol which was at $20 \mathrm{mM}$. The medium was buffered with $40 \mathrm{mM}$-HEPES, $\mathrm{pH} 7 \cdot 2$.

Mutagenesis. Tn 5 mutagenesis was carried out at $28^{\circ} \mathrm{C}$ using the procedure developed by Beringer $e t$ al. (1978). Fructose-utilizing revertants were isolated by plating $10^{8}$ mutant cells on to fructose minimal salts agar.

Nodulation and preparation of bacteroids. Pea plants (Pisum sativum L. cv. Greenfeast) in pots were nodulated by R. leguminosarum strains and bacteroids were prepared as described by Glenn et al. (1980); they were used immediately after isolation.

Radiochemicals. D-[U-14 $\mathrm{C}]$ Fructose $\left(10 \cdot 3 \mathrm{GBq} \mathrm{mmol}^{-1}\right),{ }^{3} \mathrm{H}_{2} \mathrm{O}\left(185 \mathrm{MBq} \mathrm{g}^{-1}\right)$ and $\left[{ }^{14} \mathrm{C}\right]$ inulin $(185 \mathrm{MBq}$ $\mathrm{mmol}^{-1}$ ) were purchased from Amersham.

$\left[{ }^{14} \mathrm{C}\right]$ Fructose uptake experiments. Cells were prepared and uptake experiments conducted as described by Hudman \& Glenn (1980), except that the cells were centrifuged at $22^{\circ} \mathrm{C}$ and washed with minimal salts (Brown \& Dilworth, 1975) rather than Millipore filtered before use. The scintillant was as described by Hudman \& Glenn (1980) with the addition of Triton X-100 $\left(300 \mathrm{ml} \mathrm{l}^{-1}\right)$.

Determination of cell volume. The cell volume in pellets was determined using the ${ }^{3} \mathrm{H}_{2} \mathrm{O}$ and $\left[{ }^{14} \mathrm{C}\right]$ inulin technique described by Stock $e t$ al. (1977). In the suspension used for determination of intracellular fructose concentrations, the cell volume was $1.45 \mathrm{ml}$ ( $\mathrm{g}$ dry wt cells $)^{-1}$.

Chromatography. Fructose and its phosphorylated derivatives were separated by descending chromatography on Whatman 3M paper in a solvent system containing 0.1 M-EDTA, pH 5, $1 \mathrm{M}$-ammonium acetate, $\mathrm{pH}$, and 95\% ethanol in the ratio 1:30:70, by vol. (Baumann \& Baumann, 1975). Chromatograms were run for 9-10 h during which the solvent front progressed $27-28 \mathrm{~cm}$. Sugars were detected by using a reagent consisting of a 9:1 (v/v) mixture of phloroglucinol $(0.7 \%, \mathrm{w} / \mathrm{v}$, in toluene) and $40 \%$ TCA. The toluene was allowed to evaporate and the paper was heated to $120-140^{\circ} \mathrm{C}$ for $5 \mathrm{~min}$.

Isolation of intracellular fructose. MNF3850 was grown in succinate (10 mM) plus glycerol ( $20 \mathrm{mM})$ to an $A_{600}$ of approximately 0.7 ; the cells were harvested by centrifugation, washed with minimal salts (Brown \& Dilworth, 1975 ) and resuspended in minimal salts to an $A_{600}$ of approximately $0 \cdot 5$. $\left[{ }^{14} \mathrm{C}\right] \mathrm{Fructose}(37 \mathrm{kBq})$ and cold fructose $(0.025 \mu \mathrm{mol})$ were added to $2.5 \mathrm{ml}$ cells. After $10 \mathrm{~min}$ the cells were filtered on a $0.45 \mu \mathrm{m}$ Millipore filter, washed twice with minimal salts and resuspended in $1.0 \mathrm{ml}$ salts containing $2.5 \mathrm{mM}$-unlabelled fructose. This material was heated to $100^{\circ} \mathrm{C}$ for $10 \mathrm{~min}$, centrifuged, and the resultant supernatant was chromatographed. Some $97 \%$ of the radioactive fructose was taken into the cells and of this about $90 \%$ was released by the hot water extraction. The chromatogram was dried, cut into $1 \mathrm{~cm}$ sections and the radioactivity present in each section was determined by liquid scintillation counting.

Analytical methods. Protein was determined by the Lowry method using bovine serum albumin as a standard. Fructose was estimated using the anthrone and resorcinol methods described by Herbert et al. (1971).

Enzyme assays. Cell-free extracts were prepared as described by Glenn $e t$ al. (1984). Fructokinase (EC 2.7.1.4) was measured using the glucokinase method of Lynch et al. (1975) with fructose as the substrate. Sorbitol dehydrogenase (EC 1.1.1.14) was measured using the technique of Wolff (1955). Sorbitol 6-phosphate dehydrogenase (EC 1.1.1.140) was measured by the method of Horwitz (1966) and aldose reductase (EC 1.1.1.21) by the method of Velle (1975).

Table 1. Strains of R. leguminosarum

Strain

MNF3841

MNF3850

MNF3855

MNF3851

MNF3852

\section{Derivation}

$\operatorname{Str}^{R}$ mutant of wild-type strain $300^{*}$

Tn5 ${ }^{+}$derivative of MNF3841

Tn5 $5^{+}$derivative of MNF3841

Fructose-utilizing $\left(\mathrm{Frk}^{+}\right.$) revertant of MNF3850+

Fructose-utilizing $\left(\mathrm{Frk}^{+}\right.$) revertant of MNF $3850+$

$\begin{array}{cc}\overbrace{\text { Fructose }}^{\text {Growth on: }} & \text { Glucose } \\ + & + \\ - & + \\ - & + \\ + & +\end{array}$

* Johnston \& Beringer (1975).

† Phenotypic symbol: Frk, fructokinase. 
RESULTS AND DISCUSSION

Growth properties of fructose- mutants

Tn5-induced fructokinase mutants MNF3850 and MNF3855 (Glenn et al., 1984) failed to grow on fructose, sorbitol or mannitol and grew poorly on sucrose. The parent, MNF3841, grew well on all these carbon sources. The growth of these mutants on other sugars such as glucose and arabinose and on organic acids like succinate and malate was indistinguishable from that for MNF3841. The poor growth of these two strains on sucrose was investigated further by comparing growth of the parent and mutants on glucose, glucose plus fructose, and sucrose. Cells were grown on $20 \mathrm{~mm}$-glycerol-minimal salts to an $A_{600}$ of approximately $0 \cdot 8$, centrifuged, washed and resuspended in glucose (10 mM) or glucose plus fructose (both $10 \mathrm{~mm}$ ), or sucrose $(10 \mathrm{mM})$. Samples were taken at $0.5 \mathrm{~h}$ intervals for determination of $A_{600}$. Strain MNF3841 had mean generation times of $3.5,3.3$ and $3.5 \mathrm{~h}$, respectively, on glucose, glucose plus fructose, and sucrose. The mutant strains, MNF3850 and MNF3855, had generation times on glucose similar to the parent, but were markedly slower on sucrose. Fructose depressed the rate at which the mutants grew on glucose by some $50 \%$ (Table 2 ). This growth rate inhibition was not due solely to the structural similarity of fructose and glucose, since the same result was seen when fructose was added to glycerol or succinate (Table 2). Strain MNF3851, a fructose-utilizing revertant of MNF3850, was similar to the parent strain MNF3841. Strains MNF3841 and MNF3851 grew on mixtures of glucose plus fructose or succinate plus fructose at rates identical to growth on glucose, though growth on glycerol plus fructose, or succinate plus fructose, was faster than on the single carbon source (Table 2).

\section{$\left[{ }^{14} \mathrm{C}\right]$ Fructose uptake}

Cells of MNF3841 grown on a variety of carbon sources were able to take up and metabolize labelled fructose, whereas strains MNF3850 and MNF3855 accumulated but did not metabolize fructose. These data are consistent with the constitutive nature of fructose utilization reported previously for this strain (Glenn \& Dilworth, 1981 a). [ $\left.{ }^{14} \mathrm{C}\right]$ Fructose uptake by MNF3850 was an active process since it was inhibited by azide (1 mM), 2,4-dinitrophenol (1 mM) and carbonyl cyanide $m$-chlorophenylhydrazone (0.025 mM) (Table 3$)$.

The specificity of the fructose uptake system was examined by adding various sugar and sugar phosphates $1 \mathrm{~min}$ before the addition of radioactive fructose. The addition of the phosphorylated sugars glucose 6-phosphate, fructose 6-phosphate, fructose 1-phosphate or fructose 1,6-bisphosphate (all at $2.5 \mathrm{~mm}$ ) had little or no effect on $\left[{ }^{14} \mathrm{C}\right]$ fructose uptake. Of the sugars tested, sorbose $(2.5 \mathrm{~mm})$ had the greatest effect, consistent with its structural similarity to fructose (Table 3), while glucose $(2.5 \mathrm{mM})$ decreased $\left[{ }^{14} \mathrm{C}\right]$ fructose uptake by $50 \%$. Galactose, fucose, sucrose and mannitol had no effect (Table 3 ).

Isolated bacteroids of MNF3841 failed to accumulate $\left[{ }^{14} \mathrm{C}\right]$ fructose even though they were able to take up $\left[{ }^{14} \mathrm{C}\right]$ succinate. This observation is consistent with the lack of fructose oxidation observed previously in bacteroids of this strain (Glenn \& Dilworth, 1981a). It shows that fructose, like glucose (Hudman \& Glenn, 1980) and sucrose (Glenn \& Dilworth, 1981b) cannot be transported by isolated bacteroids even though the uptake systems for all three have been shown to be constitutive in this strain (Glenn \& Dilworth, 1981a).

\section{Is the accumulated $\left[{ }^{14} \mathrm{C}\right]$ fructose phosphorylated?}

To determine if the $\left[{ }^{14} \mathrm{C}\right]$ fructose accumulated by the fructose non-metabolizing mutant MNF3850 were phosphorylated, the cell-associated radioactive material was extracted and chromatographed. There was a single peak of radioactivity accounting for more than $95 \%$ of the label applied to the chromatogram which migrated with an $R_{F}$ of 0.67 identical to that of authentic fructose. There was no evidence for phosphorylated derivatives of fructose. Identical results were obtained with strain MNF3855.

This experiment provides clear evidence that $R$. leguminosarum does not transport fructose by means of a PEP-dependent uptake system. In this respect it is different from many Pseudomonas species (Van Dijken \& Quayle, 1977; Sawyer et al., 1977). This observation together with earlier 
Table 2. Effect of fructose on the growth of various strains of $R$. leguminosarum

Rhizobium leguminosarum strains were grown in glycerol-minimal salts broth to an $A_{600}$ of approxi-
mately 0.8 , centrifuged, washed and resuspended in fresh media containing different carbon sources. At $0.5 \mathrm{~h}$ intervals samples were taken for measurement of $A_{600}$.

\begin{tabular}{|c|c|c|c|c|c|}
\hline \multirow[b]{2}{*}{ Carbon source } & \multirow[b]{2}{*}{ Strain... } & \multicolumn{4}{|c|}{ Mean generation time $(h)$} \\
\hline & & 3841 & 3850 & 3851 & 3855 \\
\hline Glucose & & $3 \cdot 3$ & 3.8 & 3.65 & $4 \cdot 0$ \\
\hline Fructose & & $4 \cdot 5$ & - & $4 \cdot 6$ & - \\
\hline Sucrose & & $3 \cdot 5$ & $9 \cdot 6$ & $3 \cdot 6$ & $9 \cdot 0$ \\
\hline Glucose/fructose & & $3 \cdot 3$ & $6 \cdot 25$ & 3.65 & $6 \cdot 5$ \\
\hline Glycerol & & $3 \cdot 75$ & 3.75 & $4 \cdot 0$ & 3.9 \\
\hline Glycerol/fructose & & 3.0 & $6 \cdot 45$ & 3.45 & 6.7 \\
\hline Succinate & & 3.9 & 3.45 & $4 \cdot 0$ & $3 \cdot 7$ \\
\hline Succinate/fructose & & ND & $5 \cdot 1$ & $3 \cdot 1$ & $5 \cdot 05$ \\
\hline
\end{tabular}

ND, Not determined. -, No growth.

Table 3. The effect of metabolic inhibitors and other sugars on $\left[{ }^{14} \mathrm{C}\right]$ fructose uptake by R. leguminosarum MNF3850

Cells were grown on glycerol $(20 \mathrm{~mm})$. The data are averages from two separate experiments. The control rate of uptake was $9 \mathrm{nmol} \mathrm{m^{-1 }}(\mathrm{mg} \text { protein })^{-1}$.

\section{Addition}

None

Carbonyl cyanide $m$-chlorophenyl

hydrazone $(0.025 \mathrm{mM})$

2,4-Dinitrophenol (1 mM)

Azide (1 mM)

Fructose 1-phosphate (2.5 mM)

Fructose 6-phosphate (2.5 mM)

Fructose 1,6-bisphosphate (2.5 mM)

Glucose 6-phosphate (2.5 mM)

Fucose (2.5 mM)

Galactose (2.5 mM)

Glucose (2.5 mM)

Mannitol (2.5 mM)

Sorbose $(2.5 \mathrm{mM})$

Sucrose $(2.5 \mathrm{~mm})$
Percentage

of control

100

1

2

2

98
103

95

108

77

110

50

98

22

107

work on glucose uptake in $R$. leguminosarum (Hudman \& Glenn, 1980) shows that this organism does not have a phosphotransferase system.

\section{Intracellular fructose concentration}

The intracellular concentration of fructose in MNF3850 and MNF3855 was determined by measuring the amount of $\left[{ }^{14} \mathrm{C}\right]$ fructose accumulated from $1 \mathrm{ml}$ of a solution containing $7 \cdot 4 \mathrm{kBq}$ $\left[{ }^{14} \mathrm{C}\right]$ fructose and $0 \cdot 1 \mathrm{~mm}$ unlabelled fructose after 5,15 and $120 \mathrm{~min}$. Accumulation was essentially complete after $15 \mathrm{~min}$, when the intracellular concentration of fructose was $30 \mathrm{mM}$, a 300 -fold increase in concentration over that in the medium. In a comparable experiment with MNF3841, only $20 \%$ of the accumulated radioactivity was water extractable. When this soluble material was separated using the paper chromatography system described previously, about $15 \%$ was identifiable as fructose, corresponding to an intracellular concentration of $0.4 \mathrm{~mm}$. Fructose 6-phosphate accounted for a further $31 \%$ of the soluble cell-associated radioactivity and $32 \%$ of the radioactivity remained at the origin, a totally different pattern to that observed in MNF3850 and MNF3855. 


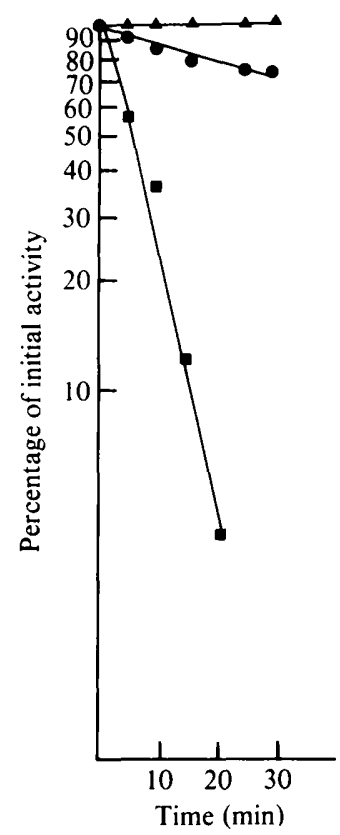

Fig. 1. The effect of fructose on the stability of fructokinase in parent and revertant strains of $R$. leguminosarum. Cell-free extracts were prepared from fructose-grown cells and incubated at $28^{\circ} \mathrm{C}$ without further addition [MNF3841 $(\triangle)$; MNF3851 ( $\square)$ ], or with the addition of 2 mM-fructose [MNF3841 (A); MNF3851 (O)]. The $100 \%$ enzyme activity was 95 and $6.8 \mathrm{nmol} \mathrm{m^{-1 }}(\mathrm{mg}$ protein) ${ }^{-1}$ for MNF3841 and MNF3851, respectively.

These experiments suggest that in MNF3850 and MNF3855 the process of accumulation of fructose, or fructose itself, or both, may cause the inhibition of growth when fructose is added to a second carbon source.

\section{Fructose-utilizing $\left(\mathrm{Frk}^{+}\right)$revertants}

Frk $^{+}$revertants of MNF3850 and MNF3855 were selected by plating on to fructose minimal salts plates, and arose at a frequency of about $2 \times 10^{-6}$ for both mutants. All such clones examined were kanamycin resistant; thus a copy of Tn5 was retained in the genome of each. Thus, the Frk ${ }^{+}$phenotype of pseudorevertants could arise from a suppressor mutation within Tn5, or within the associated fructokinase gene sequence or elsewhere in the genome. The pseudorevertant strains regained the capacity to grow on fructose, sorbitol or mannitol and grew well on sucrose (Table 2). The growth rate and final turbidity of MNF3851 (a Frk ${ }^{+}$revertant of MNF3850) on fructose (2 mM) were identical to those for MNF3841. Similarly, the rate of consumption of fructose was $0.78 \mu \mathrm{mol} \mathrm{h}^{-1}$ per $A_{600}$ unit in MNF3841 and $0.70 \mu \mathrm{mol} \mathrm{h}^{-1}$ per $A_{600}$ unit in MNF3851, compared with 0 in MNF3850.

Since both MNF3850 and MNF3855 have been shown to lack fructokinase (Glenn et al., 1984) the growth characteristics of revertants like MNF3851 and MNF3852 suggested that the fructokinase activity had been restored. The parent strain, MNF3841, had a high specific activity of fructokinase [70-80 $\left.\mathrm{nmol} \mathrm{min}^{-1}(\mathrm{mg} \text { protein })^{-1}\right]$ when grown on glycerol. However, initial attempts to demonstrate fructokinase activity in cell-free extracts of glycerol-grown revertants were unsuccessful. Even when cell-free extracts were prepared from revertant cells grown on fructose, the fructokinase activity was relatively low $\left[2-15 \mathrm{nmol} \mathrm{min}^{-1}\right.$ (mg protein) ${ }^{-1}$ ] compared with MNF3841 [100-120 $\mathrm{nmol} \mathrm{min}^{-1}$ (mg protein) $\left.{ }^{-1}\right]$. This relatively low fructokinase activity in extracts of MNF3851 and MNF3852 grown on fructose was unstable with a half-life of $15 \mathrm{~min}$ at $28^{\circ} \mathrm{C}$. When revertant extracts were stored on ice, the fructokinase activity declined with a half-life of $20-30 \mathrm{~min}$. The fructokinase activity derived from MNF3841 was completely stable at these temperatures (Fig. 1). 
To test the idea that fructokinase in the revertants may be stabilized in vivo by its sugar substrate, fructose ( $2 \mathrm{mM}$ ) was added to extracts of MNF3851 and MNF3852. The fructosetreated and control extracts were incubated at $30^{\circ} \mathrm{C}$ and samples were removed at intervals for immediate assay for fructokinase activity. The addition of fructose markedly increased fructokinase stability (half-life $2 \mathrm{~h}$ ), but the enzyme was still less stable than that in MNF3841 (Fig. 1; data shown only for MNF3851). A further twelve independently isolated revertants of both MNF3850 and MNF3855 showed a similar instability of fructokinase. Although all the revertants grew well on fructose at $28^{\circ} \mathrm{C}$, four of the fourteen, including MNF3852, failed to grow on fructose at $33^{\circ} \mathrm{C}$. Controls showed that the parent MNF3841 grew well on fructose at $33^{\circ} \mathrm{C}$ and all the revertants grew well on tryptone-yeast extract medium (Beringer, 1974), sucrose or succinate at $33^{\circ} \mathrm{C}$.

The possibility that some inhibitor of fructokinase was being produced in the revertants was investigated by a mixing experiment. An extract of glycerol-grown MNF3841 was assayed for total activity ( $59 \mathrm{nmol} \mathrm{min}{ }^{-1}$ ), while the activity in the revertant MNF3852 was 0 . When the two extracts were mixed together, the total activity remained essentially unchanged $\left(63 \mathrm{nmol} \mathrm{min}^{-1}\right)$.

Alternative pathways of fructose metabolism, via sorbitol to glucose, or via sorbitol 6phosphate to fructose 6-phosphate were excluded because of insufficient enzyme activity. Although there is an NAD ${ }^{+}$-dependent sorbitol dehydrogenase induced in cells grown on fructose $\left[80 \mathrm{nmol} \mathrm{min}^{-1}(\mathrm{mg} \text { protein })^{-1}\right], \mathrm{NADP}^{+}$-dependent aldose reductase activity was low [ $5 \mathrm{nmol} \mathrm{min}^{-1}$ (mg protein $)^{-1}$ ] with an equilibrium markedly in favour of sorbitol formation (Velle, 1975). Rhizobium leguminosarum MNF3841, like R. meliloti (Martinez de Drets \& Arias, 1970), lacks sorbitol-6-phosphate dehydrogenase. These observations support the view that in the fructose-utilizing revertants fructose is metabolized via fructokinase to fructose 6phosphate.

MNF3850 and MNF3855 both nodulate and are effective on peas, though the onset of nodulation is delayed in comparison with the parent MNF3841.

Given the precedent of fructose inhibiting growth in the fructokinase mutants, the possibility of accumulated compounds in other mutants causing similar effects cannot be ignored. If the accumulated material were to render the bacteroids unable to fix nitrogen, that mutation might erroneously be considered significant to nitrogen fixation.

This work was funded by the Australian Research Grants Scheme.

\section{REFERENCES}

BaumanN, P. \& Baumann, L. (1975). Catabolism of Dfructose and D-ribose by Pseudomonas aeruginosa. I. Physiological studies and mutant analysis. Archives of Microbiology 105, 225-240.

BERINGER, J. E. (1974). R factor transfer in Rhizobium leguminosarum. Journal of General Microbiology 84, 188-198.

Beringer, J. E., Beynon, J. L., Buchanan-WollasTON, A. V. \& Johnston, A. W. B. (1978). Transfer of the drug-resistance transposon Tn5 to Rhizobium. Nature, London 276, 633-634.

Brown, C. M. \& Dilworth, M. J. (1975). Ammonia assimilation by Rhizobium cultures and bacteroids. Journal of General Microbiology 86, 39-48.

Dilworth, M. J., McKay, I. A., Franklin, M. \& GLENN, A. R. (1983). Catabolite effects on enzyme induction and substrate utilization in Rhizobium leguminosarum. Journal of General Microbiology 129, 359-366.

Duncan, M. (1981). Properties of Tn-5 induced carbohydrate mutants of Rhizobium meliloti. Journal of General Microbiology 122, 61-67.
GlenN, A. R. \& Dilworth, M. J. (1981a). Oxidation of substrates by isolated bacteroids and free-living cells of Rhizobium leguminosarum. Journal of General Microbiology 126, 243-247.

GlenN, A. R. \& Dilworth, M. J. (1981 b). The uptake and hydrolysis of disaccharides by fast- and slowgrowing species of Rhizobium. Archives of Microbiology 129, 233-239.

Glenn, A. R., Poole, P. S. \& Hudman, J. F. (1980). Succinate uptake by free-living and bacteroid forms of Rhizobium leguminosarum. Journal of General Microbiology 119, 267-271.

GlenN, A. R., McKay, I. A., ARWas, R. \& DilWORTH, M. J. (1984). Sugar metabolism and the symbiotic properties of carbohydrate mutants of Rhizobium leguminosarum. Journal of General Microbiology 130, 239-245.

Herbert, D., Phipps, P. J. \& Strange, R. E. (1971). Chemical analysis of microbial cells. Methods in Microbiology 58, 210-236.

HoRwITZ, S. B. (1966). Mannitol 1-phosphate dehydrogenase and sorbitol 6-phosphate dehydrogenase 
from Aerobacter aerogenes. Methods in Enzymology 9 , 150-155.

Hudman, J. F. \& GlenN, A. R. (1980). Glucose uptake by free-living and bacteroid forms of Rhizobium leguminosarum. Archives of Microbiology 128, 72-77.

JOHNSTON, A. W. B. \& BERINGER, J. E. (1975). Identification of the Rhizobium strains in pea root nodules using genetic markers. Journal of General Microbiology 87, 343-350.

LynCh, W. H., McLeod, J. \& Franklin, M. (1975). Effect of temperature on the activity and synthesis of glucose catabolizing enzymes in Pseudomonas fuorescens. Canadian Journal of Microbiology 21, 1560-1572.

Martinez-De Drets, G. \& ARias, A. (1970). Metabolism of some polyols by Rhizobium meliloti. Journal of Bacteriology 103, 97-103.

Ronson, C. W. \& Primrose, S. B. (1979). Carbohydrate metabolism in Rhizobium trifolii: identification and symbiotic properties of mutants. Journal of General Microbiology 112, 77-88.
Sawyer, M. H., BaumanN, P., Baumann, L., Berman, S. M., Canovas, J. L. \& Berman, R. H. (1977). Pathways of D-fructose metabolism in species of Pseudomonas. Archives of Microbiology 112, 49-55.

Stock, J. B., Rauch, B. \& Roseman, S. (1977). Periplasmic space in Salmonella typhimurium and Escherichia coli. Journal of Biological Chemistry 252, 7850-7861.

Streeter, J. G. (1980). Carbohydrates in soybean nodules. II. Distribution of compounds in seedlings during the onset of nitrogen fixation. Plant Physiology 66, 471-476.

Van DiJken, J. P. \& Quayle, J. R. (1977). Fructose metabolism in four Pseudomonas species. Archives of Microbiology 114, 281-286.

Velle, W. (1975). Aldose reductase from seminal vesicle and placenta of ruminants. Methods in Enzymology 41, 165-170.

WolfF, J. B. (1955). Sorbitol dehydrogenase from liver. Methods in Enzymology 1, 348-350. 